\title{
A indústria dos corpos exauridos na plantation açucareira no Nordeste do Brasil
}

\author{
José Marcelo Marques Ferreira Filho
}

\section{SciELO Books / SciELO Livros / SciELO Libros}

FERREIRA FILHO, JMM. A indústria dos corpos exauridos na plantation açucareira no Nordeste do Brasil. In: OLIVEIRA, TB., org. Trabalho e trabalhadores no Nordeste: análises e perspectivas de pesquisas históricas em Alagoas, Pernambuco e Paraíba [online]. Campina Grande: EDUEPB, 2015,

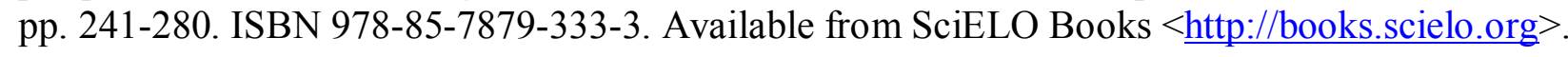

All the contents of this work, except where otherwise noted, is licensed under a Creative Commons Attribution 4.0 International license.

Todo o conteúdo deste trabalho, exceto quando houver ressalva, é publicado sob a licença Creative Commons Atribição $\underline{4.0}$.

Todo el contenido de esta obra, excepto donde se indique lo contrario, está bajo licencia de la licencia Creative Commons $\underline{\text { Reconocimento } 4.0 .}$. 


\section{A indústria dos corpos exauridos na plantation açucareira no Nordeste do Brasil}

José Marcelo Marques Ferreira Filho

19 de outubro de 1979, em algum dos incontáveis engenhos desconhecidos na zona canavieira de Pernambuco, Brasil...

General João Batista de Oliveira Figueiredo

[Presidente do Brasil]: O senhor mora nessa casa e não paga aluguel. Tem seguro?

José:[trabalhador da cana]: Não tenho nada, nada.

Figueiredo: Quer dizer que o senhor morrendo não deixa nada para a esposa e filhos?

José: Eu morrendo a usina despeja. Eu morrendo minha esposa é despejada com dois meses, porque a família não tem direito de morar na casa se o marido já morre.

Figueiredo: $E$ o INPS?

José: Eu não desconto INPS não senhor.

Figueiredo: Cadê o Jair? [Jair Soares, Ministro da Previdência Social]

Mário Andreazza [Ministro do Interior]: O problema da casa nós vamos resolver.

Figueiredo: [dirigindo-se ao trabalhador], Quer dizer que 
essa vontade que o senhor me expressou de ter uma casa vai ser concretizada. E a senhora trabalha onde?

Maria Gomes [esposa de José]: Eu trabalho no corte da cana. Saio quatro horas da manhä, com as crianças, que não estudam porque eu ponho elas pra ajudar no trabalho. Só o pai não pode sustentar sete pessoas.

Figueiredo: $O$ marido disse que não tem INPS.

Maria Gomes: Ele não tem direito a nada. Ninguém aqui tem direito a nada.

Figueiredo [indagando de Jair Soares, que acaba de chegar]: Ela está dizendo que náo tem INPS.

Jair Soares [Ministro da Previdência Social]: A legislação dá cobertura. Eu vou providenciar que o superintendente do INAMPS e do INPS tome providências.

Figueiredo: Existem muitos na situaçâo do senhor?

José: Muitos, muitos. Quando ocorre um acidente aqui, passam, cinco meses e não ganhamos nada, e sem direito. E a gente, quando vai ao hospital, eles dizem que não temos direito de fazer tratamento.

O diálogo ${ }^{1}$ entre o entáo presidente da República, General João Batista Figueiredo, e o casal de trabalhadores, José e Maria Gomes, revela um episódio pouco conhecido da história do Brasil, mas ilustrativo da realidade social coletiva no Nordeste do Açúcar. Na esteira das grandes greves que ocorriam em todo o Brasil, no final dos anos 1970, impulsionadas pelo momento histórico de relativa distensão do regime militar, a Federação dos Trabalhadores na Agricultura do Estado de Pernambuco (FETAPE) organizou, em outubro de 1979, a mobilização de mais de 100 mil trabalhadores na zona canavieira. A visita de Figueiredo às ditas terras de açúcar decorria, em parte, de uma estratégia da classe patronal para conter os ânimos dos trabalhadores que

1 CARVALHO, Ricardo R. de. As viagens do presidente. In: Jornal da República, São Paulo, 19 out. 1979, p. 5 apud BERNARDES, Denis A. de M. Octávio Ianni e a Questão Nordeste. In: COSTA LIMA, Marcos (org.). A Sociologia de Octávio Ianni: uma abordagem. Recife: EDUFPE, 2005, p. 44-45. 
haviam acabado de protagonizar a segunda maior greve da história do setor sucroalcooleiro no Estado.

De forma velada, a relaçáo de morada - em que o morador de engenho era, segundo a literatura, amplamente beneficiado pelo senhor de engenho - apareceu logo na primeira pergunta do Presidente. A referência de Figueiredo a não necessidade de pagar aluguel parece soar, de início, como certa tentativa de fazer com que José se sentisse em dívida com o senhor proprietário do imóvel em que vivia com sua família. Embutida nessa questão, parecia estar a tentativa de convencê-lo de que náo teria motivos para aderir a nenhuma greve contra patróes táo generosos que lhe permitia viver, com esposa e mais seis filhos, numa casa pela qual náo precisava assinar contrato de aluguel para nela morar. Contra tal provocação, o homem do campo imprimiu resposta precisa: "Não tenho nada, nada". A dupla negação na fala de José, provável analfabeto de pai e mãe, como se costuma dizer por essas terras, funcionava, ao mesmo tempo, como réplica e como contragolpe. A surpresa de Figueiredo - talvez nem tanto pelo fato de o trabalhador afirmar tão categoricamente nada ter, mas pela coragem da resposta enquanto ainda morava numa casa que, de fato, não lhe pertencia - fora denunciada por sua segunda pergunta. Todavia, o revide de José para ela parece náo ter conduzido o presidente a um patamar de sensibilidade que lhe permitisse evocar qualquer interjeição: logo, seguiu uma terceira pergunta, cuja resposta parece não ter tido importância aparente, a não ser pela intromissão de um interlocutor fantasma que anunciou, como se suas palavras apagassem o sofrimento de geraçóes: "O problema da casa nós vamos resolver".

Figueiredo era um homem experiente, acostumado a discursos e até capaz de vencer um debate sem ter razão. "Resolvido o problema da casa", talvez o presidente tenha achado melhor estender o interrogatório à Maria Gomes, esposa de José. A representante do suposto sexo frágil, que trabalhava no corte da cana desde as quatro horas da manhã e cuidava de mais seis filhos, foi ainda mais contundente em sua reposta: "Ele [seu marido José] não tem direito a nada. Ninguém aqui tem direito a nada". Talvez por falta 
de atenção na resposta de Maria ou, quem sabe, por simples ignorância organizada, o representante maior do Brasil faz uma última pergunta a José, a mesma que sua esposa acabara de responder. Sem perder a oportunidade, e já percebendo que aquele 'diálogo' não se estenderia por muito mais tempo, o homem do campo aproveitou para concluir denunciando o segundo maior problema, depois da fome, enfrentado em todo o Nordeste açucareiro: a falta de assistência médica em caso de doenças e acidentes de trabalho.

Este artigo trata das relaçóes entre trabalho e doenças na plantation açucareira em Pernambuco. Baseado numa análise que cruza referências da literatura médica (estudos clínicos, dietéticos e bioquímicos) com dados coletados em prontuários médicos, analisa, numa perspectiva histórica, o processo de adoecimento dos trabalhadores do açúcar. A primeira parte discute a fome e a desnutrição; já a segunda compõe uma análise conjunta de dados coletados no Arquivo do Hospital Baráo de Lucena (conhecido como Hospital das Usinas) entre os anos 1963 e 1973. Considerado em seu todo, o artigo argumenta que a maior parte das doenças que afligiam a classe trabalhadora do açúcar decorria do processo de trabalho nos engenhos e nas usinas.

No Nordeste do Brasil, a plantation açucareira produziu uma sociedade crônica e endemicamente patológica. Extensa área que congregava milhares de engenhos - unidades relativamente autossuficientes, semifechadas e dominadas por milícias privadas fortemente armadas - a plantation era, ao mesmo tempo, um espaço de poder e um modelo de produção sobremaneira sofisticado, que funcionou com base no controle corporal de centenas de milhares de indivíduos. Nesse espaço, o secular exercício de poder e violência sem limites, somados ao domínio quase absoluto do tempo e da vida dos trabalhadores do açúcar por um pequeno 
grupo de empresas, formou um exército permanente de doentes. O regime de trabalho compulsório (refletido nas amplas jornadas de trabalho), mantido mesmo depois da abolição da escravidão e sustentado com base na negação consentida dos direitos legais (férias; repouso remunerado; hora extra etc.) ${ }^{2}$, aliado à fome e à desnutrição crônica da massa de trabalhadores, era o principal elemento patógeno dessa sociedade.

As plantations tinham suas próprias leis e justiça, seus próprios costumes, moeda, moralidade e, até, sua própria linguagem. Mesmo para a maioria dos moradores de engenho em seu interior - para quem o acesso aos sítios, que garantiriam certa segurança alimentar, provou-se ser exceçáo e não regra, como se supôs por muito tempo - as supostas vantagens materiais compreendidas no regime de morada (moradia, assistência em caso de doenças e morte, acesso à lenha e água, além da proteção do senhor) existiam apenas no plano conceitual ${ }^{3}$. Nessas terras esquecidas, onde a somatória de fome e de trabalho exaustivo compunha o dia a dia de homens igualmente esquecidos, a falta de assistência médica e de medicamentos adequados e as precárias condiçóes de habitação faziam com que doenças com tratamentos relativamente simples adquirissem a gravidade que beirava o risco de morte. Sem sistema de saúde, transporte, saneamento e abastecimento alimentar fornecidos pelo Estado, os engenhos constituíam territórios situados fora da ordem jurídica normal.

A carência de postos de saúde e de hospitais dentro da plantation, aliada à extrema dificuldade de translado tanto para dentro quanto para fora dos engenhos, dificultava os primeiros atendimentos aos doentes e aos acidentados. Mesmo em época recente, a precariedade dos serviços de saúde na zona canavieira era notória. Ainda nos anos 1970, nessa vasta extensão de terra, havia

2 FERREIRA FILHO, José Marcelo Marques. Direitos conquistados, discretas esperanças: as leis, os canavieiros e os conflitos na Justiça do Trabalho (Escada, 1963-1969). Recife: Monografia do Curso de Bacharelado em História da UFPE, 2009.

3 Para mais detalhes a respeito do sistema de morada, ver DABAT, Christine Rufino. Moradores de engenho: estudo sobre as relaçóes de trabalho e condiçóes de vida dos trabalhadores rurais na zona canavieira de Pernambuco, segundo a literatura, a academia e os próprios atores sociais. Recife: 2.ed., Ed. UFPE, 2012. 
poucas unidades de saúde e municípios inteiros que não dispunham de nenhum leito para os pacientes que demandavam tratamentos mais complexos e/ou eventual internação. Mesmo nas cidades, com maior estrutura do que os engenhos, o atendimento de saúde era incerto. Por meio dos dados coletados no Censo de Assistência Médico-sanitária, realizado pela então Secretaria de Estado dos Negócios de Saúde e Assistência Social de Pernambuco, foi possível construir um mapa (Figura 1), em que se visualiza, com mais detalhes, a gravidade do problema na regiáo.
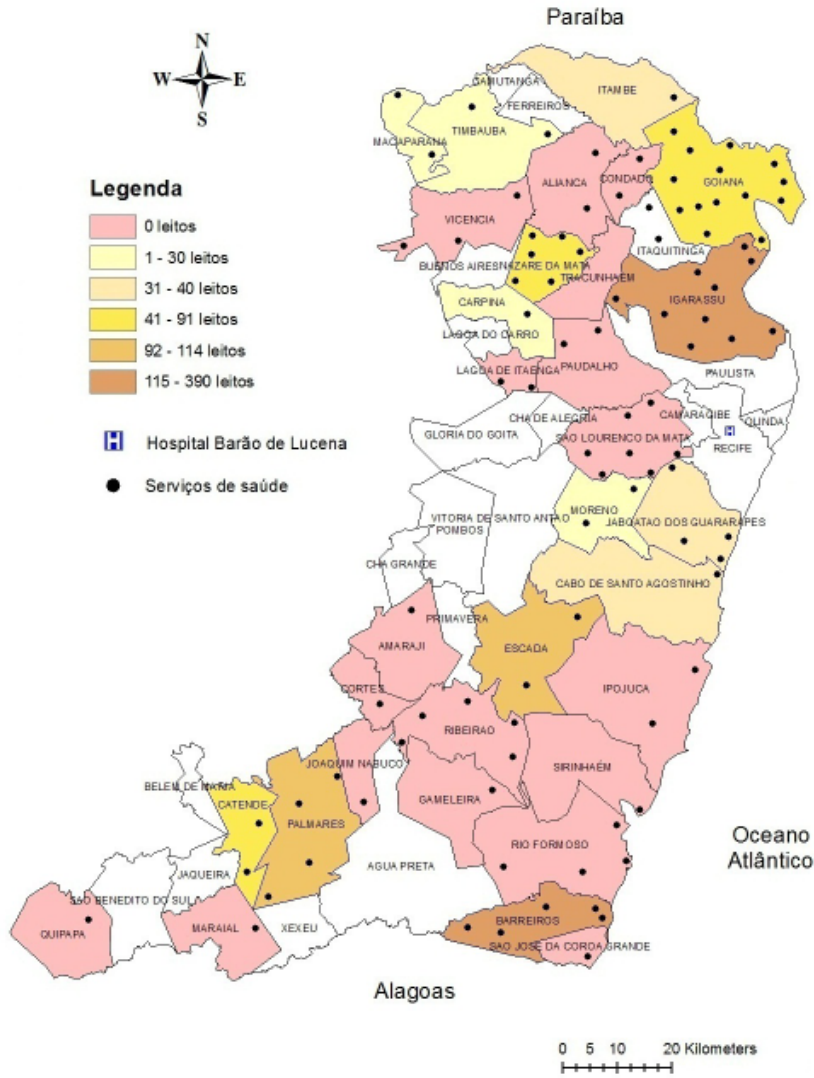

Figura 1 - Mapa da distribuição dos serviços de saúde e dos leitos na zona 
canavieira de Pernambuco nos anos 1970

Fonte: Dados coletados no "Censo de Assistência Médico-sanitária - Secretaria de Estado dos Negócios de Saúde e Assistência Social", citado por AZEVEDO, Carlos Alberto; CALDAS, Rachel; CHACON, Vamireh. Situação socioeconômica em áreas da zona canavieira de Pernambuco e Alagoas. Recife: IJNPS, 1972.

Segundo a então Fundação de desenvolvimento municipal do interior de Pernambuco (FIAM), até o final dos anos 1980, i) era raro encontrar postos de saúde na maioria dos engenhos; ii) era frequente encontrar postos médicos fechados por meses e, às vezes, por anos; iii) na maior parte dos engenhos, não existia qualquer tipo de equipamento de saúde; e iv) o translado dos doentes era feito em redes ou camas, e era necessário percorrer longas distâncias ${ }^{4}$. Em épocas mais remotas, as dificuldades enfrentadas pelos trabalhadores para um atendimento médico mais especializado eram ainda maiores, pois não existiam ou quase não podiam ser acessados, devido às limitaçóes viárias para fora dos engenhos ou às impossibilidades financeiras.

Quando o Hospital das Usinas, como era conhecido o Hospital Barão de Lucena (HBL), foi inaugurado em 1958 no Recife, ele passou a ser apresentado no discurso da classe patronal como aquele que iria amparar os trabalhadores rurais com uma assistência médica que, até então, não havia sido possível na zona canavieira de Pernambuco. Numa regiáo com serviço hospitalar tấo carente, o Hospital das Usinas era anunciado como a solução para um problema secular. Longe das unidades produtivas (como mostra a Figura 1), por vezes mais de cem quilômetros da capital, sua localização na capital denunciava certa falha no compromisso com a classe trabalhadora do açúcar.

A deficiência táo acentuada de serviços de saúde que atendessem minimamente à populaçáo canavieira demandava que os primeiros cuidados, em casos de acidentes de trabalho, fossem administrados, normalmente, pelos próprios companheiros de profissão, com assistência improvisada. A falta de material adequado e higienizado para realizar procedimentos básicos, como

4 GOVERNO DO ESTADO DE PERNAMBUCO. Levantamento sócio-econômico das pequenas localidades na Zona da Mata Sul - v. I e II. Recife: Secretaria de Planejamento, Fundação de Desenvolvimento Municipal do Interior de Pernambuco (FIAM), 1987, p. 16. 
curativos, por exemplo, agravava o quadro. Nesses momentos, os conhecimentos fitoterápicos tradicionais eram postos em prática: comumente, os trabalhadores espremiam caldo de cana para que a sacarose, eficiente cicatrizante, facilitasse a obstrução do fluxo de sangue. Dependendo da profundidade, do comprometimento dos vasos superficiais e do tempo despendido até um atendimento ambulatorial adequado, os acidentes poderiam levar a óbito. Ademais, existia um alto risco de infecção e gangrena, devido à precariedade dos cuidados e à ausência total de higiene ${ }^{5}$.

\section{Salários miseráveis e fome endêmica na plantation}

Alicerçada numa lógica puramente capitalista, a plantation açucareira produziu uma verdadeira indústria dos corpos exauridos. Quase como um elemento natural de seu caráter, os riscos que existem em todas as profissóes tornaram-se inerentes a seu arquétipo produtivo, cujo referencial absoluto se inseria no plano econômico. A baixa remuneração da classe trabalhadora, decorrente, sobretudo, do descumprimento da legislação trabalhista pela classe patronal, era elemento fundamental dessa sofisticada indústria. Sem salários que garantissem, minimamente, que se alimentassem, os canavieiros eram coagidos a trabalhar, quase sempre, além do que o corpo suportava sem manifestar algum sintoma negativo. Mesmo assim, sua baixa produtividade relativa fora interpretada como sinônimo de "malandragem e corpo mole"6.

Com a abolição da escravatura, os negros e os mestiços saídos das senzalas, ficando com a alimentação a cargo dos seus salários miseráveis, começaram por diminuir as quantidades de alimentos de sua dieta, e já não dispunham nem de combustível suficiente para produzir o trabalho

5 ALENCAR, Eloine Nascimento de. Trabalho e saúde do canavieiro. João Pessoa: Mestrado em Enfermagem em Saúde Pública/Universidade Federal da Paraíba, 1993.

6 FERREIRA FILHO, José Marcelo Marques. "Malandragem e corpo mole": a naturalização das doenças do trabalho no discurso da classe patronal canavieira em Pernambuco (19601975). In: Gênero \& História, v. VII, pp. 259-299, 2011. 
que antes realizavam. Diminuíram, então, o seu rendimento para equilibrar o déficit orgânico, sendo essa diminuição tomada pelos patróes mais reacionários como um sinal de preguiça consciente, de premeditada rebeldia do negro liberto contra o regime feudal da economia açucareira. A verdade é que a moleza do 'cabra de engenho', a sua fatigada lentidão não é um mal de raça, é um mal de fome. É a falta de combustível suficiente e adequado à sua máquina, que náo lhe permite trabalhar senáo num ritmo ronceiro e pouco produtivo ${ }^{7}$.

A despeito da discussão sobre o suposto regime feudal da economia açucareira, citado por Josué de Castro no trecho acima, e da melhor alimentação do escravo em relaçáo ao morador de engenho, a consequência imediata das dificuldades salariais enfrentadas pelos trabalhadores no pós-abolição se refletia na quantidade e na qualidade dos alimentos que sua remuneração não permitia adquirir. A gravidade da fome, no Nordeste do Brasil, fora tão acentuada e notória que, entre março e maio de 1963, o governo dos Estados Unidos, através do Interdepartmental Committee on Nutrition for National Development (ICNND), realizou uma grande pesquisa (Northeast Brazil Nutrition Survey) para propor, juntamente com o governo brasileiro, alternativas de mudanças. Os dados, que englobavam avaliaçóes clínicas, dietéticas e bioquímicas - reunidos e publicados em 1968 com o título Pesquisa Nutricional da Zona da Mata - mostraram, por exemplo, que a ingestão calórica da população dos municípios, cuja maior parte dos habitantes trabalhava na indústria sucroalcooleira, era de apenas $50 \%$ da recomendada ${ }^{8}$.

No Brasil, os investimentos norte-americanos faziam parte de

7 CASTRO, Josué de. Geografia da fome. São Paulo: Brasiliense, 1961, p. 128-129. (Edição original de 1948).

8 BATISTA FILHO, Malaquias et alii. Pesquisa Nutricional na Zona da Mata. Recife: UFPE Imprensa universitária, 1968, p. 26. 
um amplo projeto de combate ao comunismo na América Latina durante a Guerra Fria. Os esforços dos Estados Unidos para impedirem que o Nordeste se tornasse uma nova Cuba haviam levado à assinatura do chamado Acordo do Nordeste (Northeast Agreement), em 13 de abril de $1962^{9}$. Por meio dele, os Estados Unidos se comprometiam em aplicar 131 milhões de dólares no Nordeste. A United States Agency for International Development (USAID) foi encarregada de executar o projeto, porque os ianques acreditavam que o fim da fome, mesmo por meio de uma reforma agrária que causava medo à classe latifundiária, era uma estratégia antirrevolucionária que impediria o avanço do comunismo no Brasil. Mesmo assim, ainda nos anos 1960, o brasilianista Joseph Page fez referência aos nordestinos como "camponeses cobertos de doenças e morrendo de fome" ${ }^{10}$. Tempos depois, no final dos anos 1970, Robert Linhart criticou o que chamou de "aritmética da miséria” na zona canavieira ${ }^{11}$. O problema persistia...

Além do nível salarial, os desajustes no processo social de produção e distribuição de riquezas e o acesso aos bens e serviços potencialmente disponíveis eram, também, causas das deficiências nutricionais. Em última instância, "a pobreza [era] a condição comum para o aparecimento da desnutrição em escala epidemiológica"12. As carências nutricionais provocadas pela fome geravam muito mais do que organismos fragilizados com baixa imunidade. Uma dieta pouco nutritiva, além de facilitar o aparecimento de diversas doenças, provocava ao longo dos anos mutaçóes irreversíveis na estrutura óssea dos indivíduos ${ }^{13}$. Os efeitos da desnutrição crônica e endêmica ${ }^{14}$ nos corpos dos trabalhadores

9 PAGE, Joseph. A Revoluçáo que nunca houve: o Nordeste do Brasil 1955-1964. Tradução: Ariano Suassuna. Rio de Janeiro: Record, 1972.

10 Ibidem, p. 33.

11 LINHART, Robert. O açúcar e a fome: pesquisas nas regiōes açucareiras do Nordeste do Brasil. Rio de Janeiro: Paz e Terra, 1981.

12 BATISTA FILHO, Malaquias; SHIRAIWA, Tizuko. Indicadores de saúde para um sistema de vigilância nutricional. Cadernos de Saúde Pública, v.5, n.1, p. 105-116, 1989.

13 BOHAN, Merwin L. (Coord.). Northeast Brazil: Nutrition Study. March-May 1963. Washington: Department of Defense, 1965, p. 8.

14 CHAVES, Nelson. Ecologia e Nutriçăo: observação no trópico úmido. In: CHAVES, Nelson. O homem além do tempo: a palavra de um cientista que amava sua terra e sua gente. Coletânea de Artigos. Universidade Federal de Pernambuco, EDUFPE, 2007, p. 140-141. 
rurais renderam-lhes o epíteto de "Homens Gabiru". Para alguns pesquisadores, o cortador de cana no Nordeste representaria uma "nova espécie", com estrutura biológica e de adaptação à fome e as intensas jornadas de trabalho incomuns aos homo sapiens ${ }^{15}$. Em 19 de novembro de 1991, o jornal A Folha de Sáo Paulo publicou a manchete "Homem-gabiru é nova espécie no Nordeste". No ano seguinte, os pesquisadores Tarsiana Portella, Daniel Amos e Zelito Passavante, do Centro Josué de Castro, publicaram o livro Homem Gabiru: catalogação de uma espécie $e^{16}$. Os autores não apenas definiram taxonomicamente esse "novo ser", como também descreveram suas características, hábitat, hábitos, alimentação, reprodução, expectativa de vida e morfologia interna.

Entre 1991 e 1997, foram publicadas, em todo o país, inúmeras matérias sobre o legítimo representante do homem gabiru (cortador de cana, Amaro João da Silva residia em um engenho no município de Amaraji, zona canavieira de Pernambuco). Em entrevista concedida à Revista Veja, em 18 de dezembro de 1991, Amaro João denunciava sua miserável condição de vida: “Tem dia que a gente náo sabe se vai comer ou não. Eu e a mulher damos primeiro para as crianças. Depois o que sobra fica para nós" ${ }^{17}$. Em 15 de janeiro de 1997, o Diário de Pernambuco publicou: "Homem-Gabiru está doente". No final do primeiro parágrafo: "Amaro confessa[va] que já comeu muito rato do mato (um roedor herbívoro conhecido como punaré) para sobreviver. 'Se não comesse, morria de fome', diz'. Na imagem que acompanhava a reportagem, Amaro João aparecia em sua casa, humilde e sem conforto, ao lado de quatro filhos mal vestidos e de pés descalços. A matéria do enviado especial desnudava o "cotidiano de miséria" e doença (o homem gabiru havia adquirido uma broncopneumonia), mas reafirmava a tese: "representantes legítimos de uma sub-raça, sem suporte nutricional adequado, os quatro

15 Para mais de talhes ver: FERREIRA FILHO, José Marcelo Marques. "Malandragem..., op. cit:; FERREIRA FILHO, José Marcelo Marques. Usos da Natureza na Construção dos Desiguais: dos Zoológicos Humanos aos Canaviais Pernambucanos. In: Gênero \& História (UFPE), vol. 8, p. 136-161, 2013.

16 PORTELLA, T., AAMOT, D. e PASSAVANTE, Z. Homem-gabiru: catalogação de uma espécie. São Paulo: Hucitec, 1992.

17 Amaro João da Silva (protótipo da geração nanica do Nordeste). Veja, 18 de dezembro de 1991. 
filhos nanicos de Amaro também trazem estampada na face uma visível apatia”. A matéria não discutia as causas e as consequências da enfermidade contraída por Amaro. Doenças respiratórias são comuns entre os trabalhadores rurais e demais habitantes de regiôes próximas às usinas. A poluiçáo provocada pela queima da palha da cana e pelas chaminés atingia as vias aéreas superiores e provocava enfermidades respiratórias. $\mathrm{O}$ caso de Amaro João ilustrava uma constante: a falta de assistência médica e medicamentos adequados, bem como a fome e as precárias condiçóes de habitação faziam com que doenças com tratamentos relativamente simples adquirissem gravidade mais ampla, afetando ainda mais a biologia dos indivíduos.

$\mathrm{Na}$ verdade, a fome e a desnutrição crônica da população canavieira decorriam não apenas do nível baixo dos salários, mas também de uma somatória mais ampla de fatores. Em primeiro ligar, a maioria das plantations náo pagava seus funcionários com dinheiro corrente: elas possuíam moeda própria. Chamada genericamente de vales do barracão, essas moedas só tinham valor nos engenhos onde eram instituídas. Sem valor monetário fora das áreas de domínio de seu engenho específico, os vales impediam os trabalhadores de adquirirem produtos fora dos limites da cana:

Recebendo, o morador, em vales ao invés de dinheiro, ficava geralmente em débito devido aos preços exorbitantes do barracão. Dessa forma ficava atrelado ao engenho e ainda mais limitado na liberdade de dispor de sua força de trabalho vendendo-a a quem quisesse. (...) O sistema de vales/barracão (...) desmonetariza as relaçóes de trabalho fechando o trabalhador no universo isolado do engenho ${ }^{18}$.

$\mathrm{O}$ endividamento era um mecanismo fundamental na

18 CABRAL, Pedro Eugênio T. Tempo de morada: a constituiçấo do mercado de trabalho semi -assalariado na Lavoura Canavieira Pernambucana. In: SAMPAIO, Yoni. Nordeste Rural: a transiçáo para o capitalismo. Recife: Ed. Universitária, 1987, p. 39. 
manutenção da plantation. Segundo a antropóloga Beatriz Alásia de Heredia "a dívida contraída no barracão era uma norma... [ela] constituía um elemento central no processo de internalizaçáo do esquema de dominação"19. Ademais, como afirmou Garcia, "o acesso ao comércio [externo] [era] limitado geograficamente por grandes distâncias que os trabalhadores dever[iam] percorrer a pé ou em automóveis segundo suas disponibilidades monetárias e, sobretudo, pelos altos preços tradicionalmente cobrados" ${ }^{20}$. Ou seja, i) com salários baixos, devido ao náo cumprimento da legislaçáo trabalhista; ii) recebendo em vales, aceitos apenas no mundo dos engenhos; iii) forçados a comprar nos barracóes a preços acima dos praticados no livre comércio; iv) isolados geograficamente da sociedade externa..., a alimentação dos trabalhadores era determinada pelo sistema produtivo arbitrado pelas empresas. $\mathrm{O}$ isolamento era condição indispensável para que a plantation funcionasse em pleno vapor e sem empecilhos legais: nem mesmo as autoridades públicas se arriscavam a adentrar o mundo dos engenhos - territórios intocados por labirintos de velhas estradas cercadas pelo imenso "mar de cana".

O suposto acesso aos sítios, já mencionado no início deste artigo, que garantiria a cada morador de engenho um lote de terra para cultivar lavoura de subsistência e que funcionaria como complemento salarial familiar, era uma exceção. $\mathrm{O}$ sítio não era, como a literatura veiculou por longo tempo, um elemento inerente ao sistema de morada. Aqueles que chegaram a possuí-lo se queixavam de sua distância em relaçáo à casa do morador e/ou de que terrenos pouco férteis, secos e pedregosos, impróprios para o cultivo de alimentos sem uso de tecnologias e sistema de drenagem, demandariam investimentos com que os trabalhadores não podiam $\operatorname{arcar}^{21}$.

19 HEREDIA, Beatriz Maria Alásia. Formas de dominaçáo e espaço social: a modernização da agroindústria canavieira em Alagoas. São Paulo: Marco Zero, 1988, p. 121-122.

20 "Laccés au commerce est limité géographiquement par de grandes distances que les travailleurs devront parcourir à pied ou en voiture selon leurs disponibilités pécuniaires et surtout par les prix elevés, pratiqués traditionnellement par celui-ci”. GARCIA, Marie France. O Bacurau: étude de cas d'un marche situe dans une usina. Rio de Janeiro: Dissertaçáo de Mestrado em Antropologia Social/Museu Nacional do Rio de Janeiro, 1977, p. 78-79.

21 Para mais detalhes sobre o acesso aos sítios, ver DABAT, Christine Rufino. Moradores de Engenho..., op. cit. 


\section{Os trabalhadores do açúcar e o Hospital das Usinas (1963-1973)}

A má nutrição dos trabalhadores, decorrente de todos os fatores acima mencionados, somada às longas jornadas de trabalho diário, à falta de ambulatórios nas unidades fabris e de um sistema de atendimento móvel de urgência e de medicamentos adequados e suficientes, compunha uma equação quase mortal, se não pelo risco de acidente fatal nos canaviais, por doenças mantidas durante anos sem tratamento adequado. Os dados discutidos a seguir foram coletados nos livros de registro de pacientes disponíveis do Arquivo do Hospital Barão de Lucena (HBL). Por meio de uma análise detalhada dos casos de pacientes atendidos no Hospital das Usinas, em seus dez últimos anos de administraçáo (1963-1973) pelos baróes do açúcar, foi possível identificar uma série de doenças relacionadas ao trabalho. Do total de pacientes atendidos nesse período, apenas $12 \%$ (6.290 de 53.739) eram empregados de usinas e engenhos da Zona da Mata, alguns do Agreste e do Sertáo ${ }^{22}$, e outros, inclusive, de fora do estado de Pernambuco (Sergipe e Alagoas) ${ }^{23}$. A maior parte dos $88 \%$ restantes morava em bairros do Recife. As distâncias que os doentes e os acidentados percorriam para receber atendimento denunciava, em certa medida, a falta de assistência médica no interior do Estado.

Nesse período, foram atendidos desde empregados da parte administrativa das usinas, como advogados e auxiliares de escritório, até encarregados de serviços gerais, tratoristas e mecânicos. A maior parte dos pacientes foi classificada na categoria 'doméstico' (2.601 casos), seguida por trabalhador rural ${ }^{24}$ ( 1.424 casos) e operário $^{25}$ (693 casos). Entretanto, o livro de registro dos pacientes não dá detalhes sobre os internados. A ausência de uma anamnese

22 Flores (108 pacientes); Canhotinho (4 pacientes); Serra Talhada (1 paciente).

23 Laranjeiras/Sergipe (15 pacientes) e Colônia Leopoldina/Alagoas (sete pacientes).

24 Na categoria 'Trabalhador rural', incluímos: cambiteiro; rurícola; cortador de cana; limpador de cana; trabalho no campo; carreiro e vaqueiro.

25 Na categoria 'Operário', incluímos: maquinista, caldeireiro, torneiro, turbineiro, industriário, fundidor, trat. na moenda, soldador, trab. na estrada de ferro, serralheiro, carpinteiro, tratorista, eletricista, marceneiro, ajudante de eletricista, ajudante de destilador, ferreiro, foguista, ajudante de caminhão, guarda freios, ajudante de oficina, servente, motorista, destilador, chefe de tráfego, pedreiro e mecânico. 
completa dificulta o levantamento de dados mais precisos. Mesmo assim, algumas questóes podem ser alçadas. Por exemplo, o índice elevado de domésticos (2.464 do sexo feminino e 137 do sexo masculino) pode encobrir uma realidade muito mais complexa: talvez, parte deles fosse, de fato, empregados regulares.

A literatura a respeito já mostrou a importância do trabalho das mulheres e das crianças no complemento da renda familiar na região açucareira. Apesar de grávidas e sob a incumbência de cuidar dos filhos menores, como no caso de Maria Gomes, citada no início deste artigo, a maior parte das mulheres participava, diariamente, das atividades produtivas no setor agrícola. Classificá-los como domésticos, então, eximiria a empresa de encargos trabalhistas decorrentes de afastamentos do trabalho em casos de acidentes. Embora a maioria dos diagnósticos entre os 'domésticos' estivesse relacionada a partos e a problemas decorrentes, identificam-se dezenas de casos de fratura (dos ossos da perna, no $1 / 3$ inferior do fêmur, no punho, rádio, falange etc.); ferimentos (infecção no dorso da mão esquerda, na face anterior do joelho, no pé etc.); contusóes (na mão esquerda, no antebraço, no tórax, no dorso do pé etc.) e entorses (dorso-lombar, joelho, tornozelo), tipicamente relacionados ao trabalho.

Dos diagnósticos identificados nos livros de registro, aproximadamente $50 \%$ foram associados a problemas decorrentes do trabalho (Quadro 1). Na verdade, esse número poderia ser ainda mais elevado se relacionássemos algumas complicações decorrentes dos partos às atividades laborais das mulheres.

Quadro 1 - Frequência dos diagnósticos dos pacientes de usinas e engenhos atendidos no HBL (1963-1973)

\begin{tabular}{|l|l|l|}
\hline Diagnósticos & $\begin{array}{l}\text { No de } \\
\text { pacientes } \\
2357\end{array}$ & Porcentagem \\
\hline Relacionados ao trabalho & 1114 & $37,5 \%$ \\
\hline Não relacionados ao trabalho & $17,7 \%$ \\
\hline $\begin{array}{l}\text { Partos e problemas relacionados (aborto, cer- } \\
\text { vicite, cistocele, prolapso genital, ruptura peri- } \\
\text { neal, retenção de restos ovulares e placentários } \\
\text { eeclampsia) }\end{array}$ & 920 & $14,6 \%$ \\
\hline
\end{tabular}




\begin{tabular}{|l|l|l|}
\hline Diagnósticos não identificados & 1874 & $29,8 \%$ \\
\hline Outros (procedimentos clínicos e cirúrgicos) & 25 & $0,4 \%$ \\
\hline TOTAL & 6290 & $100 \%$ \\
\hline
\end{tabular}

Fonte: Dados coletados a partir dos livros de registro de pacientes (HBL, 1963-1973).

De fundamental importância na manutenção da agroindústria açucareira era a reprodução da força de trabalho. A falta de assistência médica das empresas no momento do parto era suprida, normalmente, pela mobilizaçáo coletiva e pela ajuda de parteiras, quando não da assistência sindical que, na medida do possível, enviava os casos mais graves para algum serviço de saúde da capital. No Hospital das Usinas, além de partos, foram registrados vários casos de aborto, prolapso genital e cistocele, que podem ter sido causados por excesso de esforço físico. Como já mencionado, o nível salarial arbitrado pelo setor sucroalcooleiro forçava para que o trabalho de todos da família fosse empregado com vistas a complementar a renda mínima indispensável à sobrevivência. Mesmo grávidas, o serviço das mulheres era imperativo, assim como o das crianças. Apesar de trabalhar, principalmente, em serviços menos pesados, como adubar e semear, na época da safra, partiam com seus esposos e filhos para o corte da cana. O esforço físico dispensado no trabalho não era o único agravante para o número elevado de abortos. Como o médico Nelson Chaves ponderou: "as deficiências dietéticas, durante a gestação, especialmente de proteínas e vitaminas, são responsáveis pela incidência de abortos, prematuros, natimortos, mortes neonatais e malformaçóes congênitas" 26 . Ademais, problemas nutricionais aparentemente inofensivos às mães poderiam prejudicar o concepto.

\section{As mazelas da cana}

Representando quase a metade dos diagnósticos identificados, os problemas que decorriam do trabalho estavam ligados a quatro ordens de fatores: i) dieta (22\% dos casos); ii) acidentes (32\%) 
iii) ergonomia ( $16 \%$ dos casos); e iv) fatores biológicos, químicos e físicos (30\%).

$\mathrm{Na}$ sociedade açucareira do Nordeste, as deficiências nutricionais adquiriram o caráter de problema coletivo, tanto dos trabalhadores do campo quanto dos do setor industrial da produçáo. Não se tratava de hábitos alimentares inadequados, livremente escolhidos em um leque de opçóes, mas de um cardápio historicamente infligido. A alimentação inadequada dos trabalhadores acarretava uma série de doenças, como: esplenomegalia (156 casos); colite (136 casos); anemia (110); cirrose (56); desnutrição (42); bócio (11); enterocolite (5); desidratação (2) e caquexia (1).

A fome e a desnutrição provocavam ou facilitavam o aparecimento de outras doenças. A carência protéica provocava distúrbios hormonais que poderiam estar na origem de diversos outros problemas de saúde, como o bócio, por exemplo. Infecçôes benignas entre as populaçóes bem nutridas tornavam-se muito graves na sociedade açucareira. A diminuição da imunidade acentuava a chance de se desenvolverem certas doenças. Ademais, profissóes como as de cortador de cana requerem uma alimentação rica e devem variar conforme as condiçóes climáticas e o ambiente físico onde o trabalho é executado, bem como do esforço físico exigido, da carga horária dispensada e das condiçôes higiênicas. As estratégias dos canavieiros para minorar a precariedade de sua dieta variavam de acordo com suas possibilidades: $i$ ) caçar animais silvestres, com a dificuldade de encontrá-los num ambiente dominado pela monocultura da cana; ii) pescar na entressafra, quando os rios estavam menos poluídos pelo derramamento de vinhoto; iii) chupar cana escondidos, sob pena de sofrerem penalidades físicas ou de outra ordem; iv) tomar cachaça para resistir ao ritmo intenso de trabalho:

A cachaça serviu para compensar, de certo modo, a ingestão calórica deficiente. Esse estado de subnutrição é ainda mais grave em face das verminoses, especialmente a esquistossomose, que assume proporçóes alarmantes em 
alguns municípios de Pernambuco, Alagoas e Sergipe, produtores de cana. A perda de ferro, as pequenas sangrias continuadas pelos vermes vêm tornando anêmicos numerosos indivíduos com redução da capacidade de trabalho. Com o preço elevadíssimo da carne salgada (charque), dos ovos, do leite, da carne fresca, das aves, cada dia foi se reduzindo a cota de proteínas animais. A subnutrição protéica e a esquistossomose contribuem certamente para a grande incidência de cirrose hepática. Os hospitais das capitais e das cidades interioranas nordestinas estão cheios de esplenomegálicos e cirróticos ${ }^{27}$.

A deficiência de proteínas decorrente da falta de alimentos nutritivos era agravada pela sudorese abundante provocada pelo trabalho intenso. Com o suor, iam-se também sais e outras substâncias importantes na manutenção do equilíbrio corporal. A desidratação provocava "fadiga, vulgarmente denominada de fadiga tropical' 28 .

A sorte dos operários do açúcar era semelhante: nas refeições, "alguns operários (...) molha[va]m o pão no mel depositado no dó (...), para enriquecerem em alguma coisa sua alimentação. Diz[ia]-se também na usina que os corumbas (...) alimenta[va]m-se das calorias necessárias com uma garapa, tomada no próprio trabalho, feita com algum açúcar residual" 29 .

A indústria sucroalcooleira compunha um sistema complexo que envolvia vários setores: $i)$ produção agrícola; ii) transporte; iii) fabricação de açúcar e de álcool; e iv) oficinas de manutenção

27 CHAVES, Nelson. O meio e a nutrição no Nordeste brasileiro. In: CHAVES, Nelson. O homem além do tempo..., op. cit., p. 87.

28 Idem, p. 138.

29 LOPES, José Sérgio Leite $\mathbf{O}$ vapor do diabo: o trabalho dos operários do açúcar. Rio de Janeiro: Paz e Terra, 1978. 
do parque industrial. Cada uma dessas áreas tinha uma complicada divisáo de tarefas com sistemas hierárquicos de poder semelhantes em alguns pontos e distintos em outros. Os riscos de acidentes também eram distribuídos segundo o setor produtivo, com particularidades negativas que os distinguiam. As suposiçóes que se fazem sobre a relativa simplicidade dos trabalhos no campo são, comumente, errôneas. O setor agrícola da agroindústria açucareira compunha uma complexidade de etapas que exigia trabalho diário, intenso e especializado. Ademais, limitaçóes topográficas, aliadas à tecnologia inacessível, restringiam, nos anos 1960 e 1970, o uso mais generalizado de máquinas na Zona da Mata de Pernambuco. Era o trabalho manual, sobretudo, que garantia a produçáo em terrenos acidentados.

A primeira fase de todo o processo produtivo se iniciava com o preparo do solo. A adequaçấo física, química e biológica do terreno começava pelo desmatamento da área a ser plantada com cana. Nessa fase, eram retirados os restos de outras culturas anteriormente instaladas com a derrubada de árvores. Em seguida, a atividade de roçagem, por meio de estrovengas, servia para eliminar os arbustos menores. Imediatamente depois, com o uso do gancho, o trabalhador reunia todo o material resultante da roçagem, em determinado ponto do terreno, e o queimava.

$\mathrm{O}$ arrancamento de soqueira, fase seguinte, era uma das atividades que mais exigia esforço físico. Nessa etapa, o trabalhador arrancava as soqueiras com a enxada em terrenos acidentados, o que exigia, além de força muscular, equilíbrio. Para corrigir os solos, utilizava-se a aplicaçáo de calcário que, em geral, era executada por mulheres e menores de idade. Sem luvas ou máscaras, os trabalhadores lançavam com as próprias máos ou instrumentos improvisados o produto diretamente no solo. Era a etapa derradeira antes do plantio.

Uma das fases que mais requeria cuidados era o plantio da cana de açúcar. Para garantir um número elevado de socas e minimizar os custos com o manejo do solo ou com a necessidade de outro plantio, era preciso que todo o processo fosse perfeitamente coordenado através de várias tarefas. A primeira delas era 
a rebolação. Nessa etapa, a cana a ser plantada era cortada manualmente em pedaços (rebolos) com três a quatro colmos. Essa tarefa era realizada pelo rebolador no próprio local a ser plantado. A sulcagem era a etapa seguinte. Na zona canavieira de Pernambuco, a abertura de sulcos, que afofavam e descompactavam o solo onde seriam depositados os rebolos, era feita, geralmente, de forma manual. A partir dos anos 1980, esse processo sofreu mudanças importantes, visando ampliar o rendimento agrícola. $\mathrm{O}$ aumento da concentração de cana semeada exigiu sulcos mais largos e profundos, ampliando o número de golpes de enxada na execução da tarefa. O tipo de solo, seco ou muito argiloso, e os acidentes topográficos tornavam essa operação ainda mais difícil de ser executada. A cobertura dos sulcos, assim como a adubação, também era feita de forma manual. Em todas as etapas, caminhava-se quilômetros, ao longo das ruas de cana, no caso da aplicação de adubos, com sacos de até 20 quilos.

A fase seguinte - tratos culturais - constituía em um conjunto de tarefas que visavam propiciar boas condiçóes para o desenvolvimento da planta. A eliminação das ervas invasoras era feita, na maioria dos casos, de forma manual. Elas concorriam com a cana em umidade, luminosidade, nutrição e temperatura e também poderiam ser hospedeiras de pragas que afetavam os canaviais. Mesmo assim, era praticamente impossível eliminar por completo os insetos e os fungos que atingiam os partidos de cana. $\mathrm{O}$ combate às pragas, então, poderia ser feito manualmente, como a catação de gafanhotos ou o despalhamento com foice das folhas inferiores da cana já adulta para evitar a cigarrilha, e por meio do uso de agrotóxicos com pulverizador costal. Nesse caso, em equipes de 10 a 15 pessoas, cada trabalhador bombeava, diariamente, cerca de 240 litros de produtos químicos. Como todas as outras atividades da produção da cana, a aplicação correta dos herbicidas exigia certo treinamento e experiência. Comumente, as empresas não disponibilizavam os equipamentos de proteção individual (EPI) necessários e expunham os trabalhadores a inúmeros riscos de intoxicação, sem contar as consequências desconhecidas em longo prazo, como, por exemplo, maior probabilidade de 
desenvolverem células cancerígenas.

Finalmente, a fase da colheita exigia grande coordenação das atividades. Em princípio, a área destinada ao corte sofria o processo de queima da cana. No dia seguinte, iniciava-se o corte propriamente. A cana semente - utilizada para plantio de renovação do canavial - exigia cuidados especiais e deveria ser colhida crua, com despalha manual, para evitar a destruição dos brotos. $\mathrm{O}$ facão deveria ser permanentemente desinfetado e não poderia ferir os nós da cana. Além disso, como a cana semente é sempre de primeiro corte, tende a ser mais grossa e pesada. A colheita da cana crua trazia uma série de inconvenientes: a palha tornava o canavial mais denso, dificultando o trabalho, e a presença de animais peçonhentos agravava o perigo de acidentes.

A gramínea poderia ser cortada de duas formas: amarrada ou solta. No primeiro caso, eram aplicados três movimentos: corte da cana na base; corte na parte superior, para a retirada do "olho"; e corte na altura em torno de $1 / 3$ do topo, dividindo a cana em dois pedaços; em seguida, utilizando-se o próprio "olho da cana", eram feitos feixes com 20 a 25 pedaços. O corte da cana solta, embora mais simples, também exigia grande esforço físico. Ao longo dos anos, a remuneração, antes feita por feixes, foi sendo substituída pelo pagamento por tonelada. Dessa forma, o controle/fiscalização do resultado da produçáo, antes a cargo dos fiscais da usina, passou a ser exercido pelo próprio trabalhador. Entretanto, o cortador de cana não tinha condiçôes de verificar, ele mesmo, a exatidáo da balança usada pelo engenho ou usina.

O esforço físico dispensado no corte manual da cana estava condicionado a variáveis como: $i$ ) condiçóes topográficas, se em morros, várzeas, terrenos planos; ii) a qualidade biológica das variedades de cana cultivadas, isto é, volume cilíndrico e peso; iii) a cana ter sido queimada ou não; iv) o espaçamento entre as carreiras de cana; $v$ ) as exigências posteriores ao corte, se solta ou amarrada etc. A produtividade do corte dependia, também, da habilidade de cada trabalhador, de sua capacidade física, experiência, estado nutricional, idade, sexo, altura e índice de massa 
corporal $^{30}$ : "[havia] uma relação direta entre a qualidade e quantidade dos alimentos consumidos, o ambiente físico, as condiçóes de trabalho, a eficiência muscular e a produtividade" ${ }^{31}$. Naturalmente, o rendimento das atividades, ao longo da jornada diária, diminuía, e isso levava o trabalhador a ficar mais tempo no canavial, sem pausas para descanso. A última etapa da fase de colheita era o transporte da cana até as moendas. Normalmente, após o corte, a cana era levada sobre o lombo de bois e de mulas. Em terrenos acidentados, entretanto, os cambiteiros se encarregavam de transportar, nos próprios ombros, os feixes de cana.

As condiçóes de trabalho nos canaviais eram marcadas por uma lógica que privilegia a produção, em detrimento da mão de obra. A herança escravista permitiu que o processo de trabalho, em sua dimensão mais ampla, fosse reproduzido no sistema de morada. Com o controle absoluto do tempo de vida e da força de trabalho dos canavieiros, as plantations garantiam a manutençáo de um rígido sistema de dominação. A rotina dos trabalhadores rurais seguia a monotonia que lhes definia. $\mathrm{Na}$ alvorada, tinha início o dia de trabalho. O deslocamento até o local das tarefas, quando não era realizado a pé, por vários quilômetros, era feito por ônibus ou caminhos em péssimo estado. Neles, os trabalhadores eram transportados juntamente com suas ferramentas de trabalho, o que favorecia ainda mais o risco de acidentes. Nos canaviais, os riscos começavam desde o momento da queima da

30 SPURR, G. B.; BARAC-NIETO, M.; MAKSUD, M. G. Productivity and maximal oxygen consumption in sugar cane cutters. American Journal of Clinical Nutrition, v.30, 1977, p. 316-321.; SPURR, G. B.; BARAC-NIETO, M.; MAKSUD, M. G. Efficiency and daily work effort in sugar cane cutters. In: British Journal of Industrial Medicine, v. 34, n.2, May 1977, p. 137-41; SPURR, G. B.; BARAC-NIETO, M.; MAKSUD, M. G. Energy expenditure cutting sugarcane. Journal of Applied Psychology, v.39, n.6, 1975, p. 990-996; SPURR, G. B.; MAKSUD, M. G.; BARAC-NIETO, M. Energy expenditure, productivity, and physical work capacity of sugarcane loaders. The American Journal of Clinical Nutrition, v. 30, Oct. 1977, p. 1740-1746; SATYANARAYANA, K.; NAIDU, A.N.; CHATTERJEE, B.; RAO, N. Body size and work output. American Journal of Clinical Nutrition, v.30, 1977, p. 322-325; VITERI, Fernando; TORUN, Benjamín. Ingestión calórica y trabajo físico de obreros agrícolas en Guatemala: efecto de la suplementación alimentaria y su lugar en los programas de salud. Boletín de la Oficina Sanitaria Panamericana, v.78, 1975, p. 58-74, 1975; PIMENTEL, David; PIMENTEL, M. Food, Energy and Society. London, 1979.

31 CHAVES, Nelson. Alimentação do Trabalhador. In: CHAVES, Nelson. O homem além do tempo..., op. cit., p. 152-153. 
cana. A falta de experiência no ofício ou uma inesperada mudança na direção dos ventos poderiam transformar o que era uma atividade "controlada" num incêndio em grandes proporções.

Os dados disponíveis no Hospital das Usinas registram, expressamente, apenas cinco casos de acidentes de trabalho. Todavia, por meio de uma análise mais acurada da relação entre diagnósticos e profissão dos pacientes, foi possível identificar a possibilidade de índice muito mais elevado, como detalha o Quadro 2. Pouco mais de $50 \%$ desses casos foram registrados entre trabalhadores rurais, seguidos de domésticos (13\%) e operários (7\%):

Quadro 2 - Diagnósticos dos pacientes de usinas e engenhos atendidos no HBL relacionados aos riscos de acidentes (1963-1973)

\begin{tabular}{|l|l|l|}
\hline Diagnósticos & No de pacientes & Porcentagem \\
\hline $\begin{array}{l}\text { Fraturas (ossos da perna, pé, ombro, } \\
\text { mão, braço etc.) }\end{array}$ & 314 & 41,6 \\
\hline $\begin{array}{l}\text { Contusão (região lombar, pé, perna, joe- } \\
\text { lho, ombro etc.) }\end{array}$ & 155 & 20,6 \\
\hline $\begin{array}{l}\text { Ferimentos (tornozelo, perna, tórax, pu- } \\
\text { nho, mão etc.) }\end{array}$ & 147 & 19,5 \\
\hline $\begin{array}{l}\text { Entorse (dorso-lombar, joelho, tornoze- } \\
\text { lo, punho etc.) }\end{array}$ & 44 & 5,8 \\
\hline $\begin{array}{l}\text { Luxação (quadril, ombro, cotovelo, pole- } \\
\text { gar etc.) }\end{array}$ & 24 & 3,2 \\
\hline $\begin{array}{l}\text { Lesões (tendões, joelho, punho, polegar } \\
\text { etc.) }\end{array}$ & 15 & 2,0 \\
\hline Corpo estranho (punho, perna, face etc.) & 12 & 1,6 \\
\hline Queimaduras & 9 & 1,2 \\
\hline $\begin{array}{l}\text { Traumatismo (raquimedular, coxa, } \\
\text { crânio-encefálico) }\end{array}$ & 8 & 1,1 \\
\hline Esmagamento dos ossos da mão & 7 & 0,9 \\
\hline $\begin{array}{l}\text { Amputação traumática (falange, podo- } \\
\text { dáctilo etc.) }\end{array}$ & 6 & 0,8 \\
\hline Secção dos tendões & 3 & 0,4 \\
\hline
\end{tabular}




\begin{tabular}{|l|l|l|}
\hline Cicatriz (pé e mão) & 2 & 0,3 \\
\hline Hematoma (região lombar e coxa) & 2 & 0,3 \\
\hline Escoriações dorso-lombar & 2 & 0,3 \\
\hline Deslocamento da pele do dorso do pé & 1 & 0,1 \\
\hline Deslocamento do fêmur & 1 & 0,1 \\
\hline Disjunção do núcleo epifisário & 1 & 0,1 \\
\hline Torcicolo traumático & 1 & 0,1 \\
\hline TOTAL & 754 & $100 \%$ \\
\hline
\end{tabular}

Fonte: Dados coletados a partir dos livros de registro de pacientes (HBL, 1963-1973).

Não há dúvida de que a falta de EPI pode explicar parte dos casos de fraturas, contusóes, ferimentos e entorses, mas, provavelmente, não era o único motivo. Além dos próprios riscos inerentes às profissóes com objetos cortantes, a maior parte desses acidentes era provocada pela fadiga. Segundo a literatura médica, existe toda uma patologia da fadiga, não somente de certos órgãos, mas, sobretudo, resultante do esforço do organismo para se adaptar a todos os choques e se defender dos desequilíbrios. $\mathrm{O}$ cansaço acumulado não só esgotava os músculos dos trabalhadores do açúcar, como também repercutia no conjunto do corpo e do cérebro ${ }^{32}$. Ele fazia com que, para acionar um músculo, fosse necessário um esforço cada vez maior do cérebro. A atenção diminuía e, com ela, a velocidade dos reflexos, que aumentava a tendência a falhas. Em alguns casos, a exaustão poderia desordenar a atividade cerebral a tal ponto que provocava a perda de raciocínio dos movimentos. Ademais, a repetição da atividade de corte da cana fazia com que muitos trabalhadores realizassem as tarefas de

32 CHAUCHARD, Paul. La Fatigue : " que sais-je ? ». Le point des connaissances actuelles. Paris: Presses Universitaires de France, 1959. 
forma condicionada, e isso aumentava os riscos de acidentes ${ }^{33}$.

Os riscos multiplicavam-se com trabalhadores idosos, gestantes e crianças, sem contar os que permaneciam nas atividades mesmo já doentes. A perda natural da habilidade, dos reflexos e do controle sobre os movimentos musculares ampliava a probabilidade de acidentes para os idosos. $\mathrm{O}$ aumento de peso, nas gestantes, e outros sintomas da gravidez, somados aos cuidados com o bebê, exigiam do pré-parto hábitos que as empresas não cultivavam. No caso das crianças, a falta de habilidade e de experiência, mais o descompasso entre porte físico e tamanho dos instrumentos ampliavam as chances de acidentes. Além disso, diversos fatores expunham os indivíduos às contusóes, até mesmo o menor choque. Segundo a literatura médica, pessoas que não comem alimentos frescos e crus, com carência de Vitamina $\mathrm{C}$ ou que não ingerem quantidades suficientes de água têm capilares frágeis e são mais susceptíveis a sofrer contusóes.

O esforço físico exigido no corte da cana, sobretudo em terreno acidentado, comumente atingia as articulaçóes, que, submetidas a movimentos bruscos, por vezes, poderiam romper os ligamentos. A má colocação dos pés ou um simples tropeçar que forçasse as articulaçóes a um movimento para o qual não estavam habilitadas poderia provocar uma entorse, inclusive com lesóes na cápsula fibrosa que reveste a articulaçáo. As luxaçôes ocorriam, normalmente, devido a grandes choques, quando o osso era deslocado e deixava de estar unido à articulação. Estudos recentes afirmam que o trabalhador rural que cortar, em média, 12 toneladas de cana por dia o faz à base de 370.000 golpes de facáo; 37.000 flexóes nas pernas para golpear a gramínea; caminha quase 9.000 metros; carrega nos braços as 12 toneladas de cana, em montes de 15 quilos cada um, completando 800 trajetos $^{34}$. Nesse

33 VALENÇA, Vanessa. Condiçóes de trabalho, produtividade e riscos à saúde do trabalhador na atividade do corte manual de cana: um estudo de caso na Usina Santa Adélia. São Carlos: Dissertação de Mestrado do Programa de Pós-graduação em Engenharia de Produção/UFSCar, 2007.

34 THOMAZ JÚNIOR, Antônio. Não há nada de novo sob o sol num mundo de heróis! (A civilização da barbárie na agroindústria canavieira). In: Pegada, Presidente Prudente, v.8, n.2, dezembro de 2007. 
esforço, os canavieiros perdiam, em média, sete a nove litros de água por jornada, o que resultava na falta de sais e provocava câimbras e náuseas.

A completa ausência de primeiros socorros nos canaviais agravava os casos de acidentes. As usinas e os engenhos não disponibilizavam ambulâncias ou outros meios de transporte. Além disso, as dificuldades de comunicação, associadas a longas distâncias entre os campos de cana e os serviços de saúde mais próximos, faziam com que, nesses casos, os trabalhadores devessem esperar até o final do expediente para ser removidos.

No setor industrial da produção, as condiçóes de trabalho também eram precárias. As atividades requeridas tanto na fabricação do açúcar quanto em todo o complexo de oficinas que existiam para manter a usina em funcionamento, potencializavam os riscos de doenças e acidentes. O antropólogo José Sérgio Leite Lopez descreveu como "as longas jornadas de trabalho exaur[ia]m, de maneira rápida e violenta, os músculos e nervos dos operários" 35 . Devido à profunda especialização das tarefas, alguns operários, por vezes, trabalhavam 24 horas seguidas. Nesses casos, o argumento da classe patronal se embasava no artigo $61^{\circ}$ da CLT $^{36}$, que permitia a extensão da jornada de trabalho para serviços considerados inadiáveis. A prática, contudo, segundo Leite Lopes, generalizouse a ponto de transformar o trabalho nas fábricas num "regime de urgência e emergência” absoluto. A própria concepção das construçóes, o ambiente fabril e seus compartimentos, andares e seçôes comumente eram projetados sob a lógica produtivista, o que tornava os metalúrgicos do açúcar parte vulnerável do processo ${ }^{37}$.

35 LOPES, José Sérgio Leite. O vapor do diabo..., op. cit., p. 61.

36 CLT, Art. 61. "Ocorrendo necessidade imperiosa, poderá a duração do trabalho exceder o limite legal ou convencionado, seja para fazer face a um motivo de força maior, seja para atender à realização ou conclusão de serviços inadiáveis ou cuja inexecução possa acarretar prejuízo manifesto".

37 "A conjugação do fato de que a própria construção da máquina, numa produção capitalista, nunca incorpora o princípio da segurança física e mental de seu operador humano com o trabalho repetitivo e monótono da longa duração diária característica da usina acarreta tanto a inevitabilidade quanto a frequência dos acidentes de trabalho em todas as seçóes da usina”. LOPES, José Sérgio Leite. O vapor do diabo..., op. cit., p, 90. 
Além dos acidentes, grande parte dos problemas de saúde dos trabalhadores da cana era causada por excessos acumulados que não se manifestavam de forma imediata, mas em intervalos prolongados de tempo. Estudos recentes constataram que, comumente, as queixas mais frequentes entre os trabalhadores rurais são: fortes dores no pescoço, nos ombros, nos braços e dores de cabeça. Para a maior parte deles, entretanto, doença poderia significar apenas a impossibilidade de trabalhar. Segundo Eloine Nascimento ${ }^{38}$, a concepçáo de saúde dos canavieiros estava intimamente ligada ao que eles eram capazes de produzir. $\mathrm{O}$ trabalho que seu estado físico lhe permitiria executar, para suprir as necessidades familiares, era seu referencial de saúde. $\mathrm{Na}$ maioria dos casos, os canavieiros só procuravam um médico quando os sintomas os impediam de trabalhar, mesmo porque um dia sem trabalho significava salários ainda mais reduzidos. Caso contrário, continuavam exercendo suas atividades mesmo com dificuldades, com os riscos de uma recuperaçáo mais prolongada, ou, até, a impossibilidade de continuar a fazer as tarefas habituais.

Nos arquivos do Hospital das Usinas, os problemas mais comuns entre os pacientes de usinas e engenhos foram as hérnias (267 casos), provocadas, sobretudo, pelo aumento da pressão abdominal requerido em várias atividades, tanto no setor rural, quanto na parte industrial da produção de açúcar e de álcool. Além disso, a excessiva demanda física sobre a regiáo lombar, por meio de levantamentos de objetos pesados ou movimentos repentinos, podia causar diversos outros problemas.

O cortador inicialmente se posiciona para o corte ficando com as pernas levemente abertas, com o pé esquerdo mais à frente do direito. A seguir, ele pega com a mão esquerda o feixe de cana a ser cortado (3 a 5 varas de cana), eventualmente 
usando o gancho para aproximar essas varas. Nesse momento, a mão esquerda encontra-se na altura dos ombros, e o braço esquerdo entendido. Em seguida, o cortador se abaixa, e com um movimento em arco do braço direito (acompanhado pelo tronco) ele golpeia as varas de cana próximas à raiz (onde a concentração de sacarose é maior e evitando prejuízos à formação das socas) cortando-a. Eventualmente, esse movimento é feito mais de uma vez, para cortar todas as varas que compóe o feixe. Cortada a base, o cortador ergue-se e continua sustentando o feixe com a mão esquerda aplicando-lhe um movimento de rotação que faz com que as varas aproximem-se da posição horizontal. Ao mesmo tempo, é feito um pequeno movimento de rotação do tronco em torno de seu eixo, de forma a posicionar a ponteira (ponta superior) da cana acima do espaçamento entre as fileiras de planta. Com um novo golpe de facáo aplicado com a mão direita, a ponteira é cortada, caindo no solo entre as fileiras. Na mão esquerda ficam as varas de cana, que são colocadas depois no solo (no lado da fila contrário aquele que caiu a ponteira cortada, com mais uma flexão do tronco $)^{39}$.

Lesôes repetitivas ou pressão exercida sobre os discos intervertebrais poderiam lesar a coluna. A maior parte dos estresses mecânicos provocados pelo trabalho intenso e invariável era absorvida pelos discos que começavam a perder água e, com ela, sua capacidade de atuar como amortecedores das pressóes exercidas sobre a coluna. Isso levava mais estresse ao anel externo produzindo mais

39 CAMAROTTO, J. et al. Análise do processo de corte da cana-de-açúcar. São Carlos: DEP/UFScar, [s/d] citado por PAIXÃO, Marcelo Jorge de Paula. No coraçáo do canavial: estudo crítico da evolução do complexo agroindustrial sucro-alcooleiro e das relaçóes de trabalho na lavoura canavieira. Rio de Janeiro: UFRJ (Diss. de Mestrado), 1994, p, 198. 
fissuras e fazendo com que esse processo de produção de lesôes se transformasse em um círculo ininterrupto. Movimentos bruscos ou mau jeito podiam, também, causar torcicolo com ferimentos nas articulaçóes da coluna ou na região do pescoço. Outros diagnósticos frequentes de problemas ergonômicos foram: artrite e artrose (fêmur, coxa, joelho, coluna etc.), 58 casos; lombalgia (13 casos); varizes (10); bursite (3); esporão do calcanhar (3); ciática (2); rigidez do joelho (2); hemartrose do joelho (2); calos nos pés (1); discopatia lombar (1); distensão lombar (1); escoliose dorso-lombar (1); mialgia (1) e espondilite traumática (1).

A deterioração dos componentes da articulaçãoo (osso, cápsula articular, tendôes e cartilagens) era, comumente, provocada por movimentos em excesso, que causavam microlesôes ao longo dos anos. Além de dores intensas, as artrites e as artroses acompanhavam restriçóes dos movimentos. As lombalgias eram causadas por esforços repetitivos, excesso de peso; pequenos traumas; condicionamento físico inadequado; erro postural e posição não ergonômica no trabalho. As longas caminhadas exigidas nos trabalhos agrícolas, bem como a realização de todas as tarefas em pé, sem pausas regulares para descanso, podiam levar à formaçáo de varizes e esporóes, além de calos e outros problemas relacionados. Ademais, o excessivo esforço físico, somado com a postura inadequada durante o trabalho, gerava tensóes musculares e causava problemas como ciática e mialgia.

Se o regime de trabalho, incluindo duração, intensidade e ritmo, representava um dos principais fatores no tocante aos problemas ergonômicos e de acidentes, as condiçôes ambientais em que os trabalhadores viviam e executavam suas tarefas tornavam-nos suscetíveis a uma série de outras moléstias. Todas as pesquisas realizadas sobre as condiçôes de habitação dos moradores de engenho no Estado são unânimes em reafirmar sua total precariedade. O relatório já citado do Governo do Estado de Pernambuco, em 1987, constatou que a maior parte da água consumida pela 
população da zona canavieira "[era] geralmente proveniente de cacimbas a céu aberto, em precárias condiçôes de higiene e fortemente poluídas, constituindo-se em um dos fatores responsáveis pela ocorrência de grande parte das doenças da região" ${ }^{40}$. A mesma pesquisa relatou deficiências graves no sistema de esgotamento sanitário nas habitaçóes das usinas e dos engenhos.

A maior parte dos casos de problemas de saúde relacionados aos fatores biológicos, químicos e físicos que chagaram ao Hospital das Usinas afetou trabalhadores rurais (aprox. 28\%), seguidos de 'domésticos' (23\%) e operários (11\%). O fator biológico representava risco imediato para tarefas realizadas em locais insalubres e sem uso de equipamentos apropriados. O índice elevado de pacientes atendidos com parasitoses (Quadro 3) demonstra a gravidade do problema na zona canavieira. Malaquias Batista defende que elas sejam consideradas doenças ocupacionais, na medida em que os trabalhadores eram coagidos a usar águas contaminadas ${ }^{41}$.

Quadro 3: Diagnósticos dos pacientes de usinas e engenhos atendidos no $\mathrm{HBL}$ relacionados aos riscos biológicos, químicos e físicos (1963-1973)

\begin{tabular}{|l|l|l|}
\hline Diagnósticos & Node pacientes & Porcentagem \\
\hline $\begin{array}{l}\text { Parasitoses (amebíase, tuberculose, as- } \\
\text { caridíase, ancilostomose, giardíase, es- } \\
\text { quistossomose, febre tifoide, poliomielite, } \\
\text { tétano, coqueluche) }\end{array}$ & 288 & 40,1 \\
\hline $\begin{array}{l}\text { Abscessos (quirodáctilo, tornozelo, joe- } \\
\text { lho, tórax etc.) }\end{array}$ & 98 & 13,6 \\
\hline Tuberculose pulmonar & 67 & 9,3 \\
\hline Bronquite & 38 & 5,3 \\
\hline Úlcera da córnea & 30 & 4,2 \\
\hline Asma & 26 & 3,6 \\
\hline Osteomielite & 26 & 3,6 \\
\hline Conjuntivite (traumática e subaguda) & 26 & 3,5 \\
\hline
\end{tabular}

40 PERNAMBUCO. Levantamento socioeconômico..., op. cit., p, 16.

41 Entrevista com Malaquias Batista Filho citado por DABAT, Christine R. Moradores de Engenho..., op. cit., p. 479. 


\begin{tabular}{|l|l|l|}
\hline Pneumonia & 25 & 3,5 \\
\hline Eczema & 21 & 2,9 \\
\hline Gangrena & 11 & 1,5 \\
\hline Dermatite & & 1,1 \\
\hline Corpo estranho no olho & 8 & 1,1 \\
\hline Estafiloma de córnea & 8 & 1,1 \\
\hline Traumatismo no olho & 6 & 0,8 \\
\hline Ferimento no olho & 4 & 0,6 \\
\hline Leucoma da córnea & 4 & 0,6 \\
\hline Mí́ase do ouvido & 3 & 0,4 \\
\hline Impetigo & 2 & 0,3 \\
\hline Epistaxe & 2 & 0,3 \\
\hline Micose nasal & 2 & 0,3 \\
\hline Catarata traumática & 2 & 0,3 \\
\hline Pterígio & 2 & 0,3 \\
\hline Infecção do cotovelo & 1 & 0,1 \\
\hline Escabiose & 1 & 0,1 \\
\hline Esporotricose & 1 & 0,1 \\
\hline Empiema pleural & 1 & 0,1 \\
\hline Escrofulose & 1 & 0,1 \\
\hline Alergia nasal & 1 & 0,1 \\
\hline Ceratite & 1 & 0,1 \\
\hline Eritema & 1 & 0,1 \\
\hline Esfacelo da córnea & 1 & 0,1 \\
\hline Hemorragia subconjuntival & 718 & 0,1 \\
\hline Edema das conjuntivas & & \\
\hline TOTAL & & \\
\hline Font: Dados coletados & & \\
\hline
\end{tabular}

Fonte: Dados coletados a partir dos livros de registro de pacientes (HBL, 1963-1973).

O modo como o espaço era ocupado distribuía, de forma desigual, as possibilidades de indivíduos saudáveis adquirirem certas patologias. Modos diversos de inserção no processo produtivo 
definiam tanto os grupos com mais ou menos risco de adquirirem certas doenças, quanto seus efeitos diferenciados ${ }^{42}$. A literatura médica elenca três níveis condicionantes que contribuem para a multiplicação das parasitoses: i) Bioecológico (condiçóes ambientais que otimizam a reprodução dos vetores e propiciam a sobrevivência dos parasitos; ii) Socioecológico (características ambientais modificadas pela ocupação social do espaço: construçóes, práticas agrícolas, formas de eliminação dos dejetos etc.) e iii) Sociocultural (relacionados a processos históricos e políticos, como o nível educacional, por exemplo) ${ }^{43}$. Ou seja, os níveis de ocorrência e a gravidade que as parasitoses poderiam adquirir estavam relacionados ao ambiente social, econômico e biológico em que vivia o homem na Zona da Mata de Pernambuco, que agravavam o já "espoliado estado de saúde das populaçóes dessa área" ${ }^{44}$.

No setor agrícola, os trabalhadores eram expostos a riscos químicos e físicos. Os olhos eram os órgáos mais afetados. A falta de óculos de proteçáo, poeira, fumaça e fuligem proveniente da queima da palha da cana, o próprio pelo da cana e poluentes lançados no ar pelas chaminés das usinas etc. ampliavam as possibilidades de acidentes. A soma dos casos que envolviam problemas nos olhos (conjuntivite e catarata traumática; presença de corpo estranh;, estafiloma, traumatismos; ferimentos; leucoma; pterígio; ceratite; esfacelo da córnea; hemorragia subconjuntival e edema das conjuntivas) teve uma representação significativa em relação ao total (13\%). Na parte industrial da produção, as condiçôes eram semelhantes: "ambiente impregnado de partículas provenientes do bagaço da cana esmagada, que irrita[va]m o exercício da visão e a respiração dos operários" ${ }^{45}$.

A poluição do ar afetava as vias aéreas, provocando uma série

42 MOZA, Patrícia Ganzenmüller; PIERI, Otávio Sarmento; BARBOSA, Constança Simôes; REY, Luís. Fatores sócio-demográficos e comportamentais relacionados à esquistossomose em uma agrovila da zona canavieira de Pernambuco, Brasil. Cadernos de Saúde Pública, v.14, n.1, p. 107-115, jan.-mar. 1998.

43 BARBOSA, C. S. et alii. Esquistossomose: reproduçáo e expansão da endemia no Estado de Pernambuco no Brasil. Revista de Saúde Pública, v.30. n.6, 1996.

44 CHAVES, Nelson. Ecologia e Nutriçăo: observação no tropico úmido. In: CHAVES, Nelson. O homem além do tempo..., op. cit., p. 137.

45 LOPES, José Sergio Leite. O vapor do diabo..., op. cit., p. 85. 
de doenças, como tuberculose pulmonar, bronquite, asma, pneumonia, empiema pleural, micose e alergia nasal, sobretudo no período da safra ${ }^{46}$. As variaçóes de temperatura também contribuíam com o processo. $O$ trabalho realizado sob o sol escaldante ou forte chuva trazia inconvenientes invisíveis que o setor empresarial não levava em consideraçáo. A inalaçáo dos agrotóxicos dispersos no vento agravava o quadro geral e podia causar graves problemas de pele, como eczema, dermatite, impetigo, escabiose, esporotricose e eritema, inflamaçóes de pele típicas entre os trabalhadores rurais:

Eu sinto uma agonia no corpo, a gente tem vontade de ir prá uma sombra, mas não pode, a gente vai tomar um repouso ao meio-dia, ai eles tão falando que é pra a gente botar a cana abaixo. A gente não pode sair do sol de jeito nenhum, só quanto ele for embora. Tem muitos que dão agonia, molha a roupa, assa muito a gente, mas pede prá largar, mas eles não querem largar ${ }^{47}$.

A poluiçáo ambiental provocada pelas usinas agravava a situação e afetava, direta ou indiretamente, a totalidade da população bem como as 'lavouras brancas', os rios, os poços e os açudes. A água era, em muitos casos, vetor de várias doenças. A exposiçáo a toxinas nocivas no setor fabril geralmente era vista pela classe patronal como um mal menor. Os operários do açúcar também reclamavam das condiçóes no interior das fábricas, onde o vapor do diabo "estoura[va] o couro todinho (...), intestino e fígado, tudo intoxicado":

Aí eu fui pra fabricação, fui dosar. Continuei dosando aí passei uns oito anos dosando. Depois,

46 CANÇADO, José Eduardo Delfini. A poluiçáo atmosférica e sua relaçáo com a saúde humana na regiáo canavieira de Piracicaba - SP. São Paulo: Tese de Doutorado em Medicina/USP, 2003.

47 Fala de um canavieiro citado por ALENCAR, Eloine Nascimento de. Trabalho e saúde do canavieiro..., op. cit., p. 83. 
devido ao cheiro do enxofre, eu digo: 'não tá dando', aí eu falei, aí o chefe trocou, ei eu fui pra o esquenta-caldo, e do esquenta-caldo vim pra cá, pra dosagem. $\mathrm{Na}$ dosagem, tem épocas onde a fumaça, indo na gente, a gente arrota. É o enxofre puro. A fumaça penetra mesmo. E às vezes, a enxofreira mesmo dá aquele arroto. Aí sai aquele fumaceiro, não tem quem aguente. Olhe, bateu nos olhos é o mesmo que bater pimenta. Arde, arde que nem pimenta ${ }^{48}$.

A complexidade dos problemas para os adoentados que precisavam abandonar, temporariamente ou não, o trabalho para procurar tratamento médico especializado perpassava por um verdadeiro dilema: não podiam abandonar o emprego porque, como José e Maria Gomes no início deste artigo, não contavam com seguro e outros benefícios, mas precisavam dele para alimentar a si próprios e suas famílias.

Os problemas enfrentados pelos trabalhadores doentes afetavam toda a família, não apenas por causa da doença, em si, e todos os inconvenientes que ela trazia em termos de biológicos, mas também porque afetava diretamente a renda familiar. Um membro da família doente significava um braço a menos para o trabalho. Os demais componentes familiares deveriam, então, trabalhar em dobro para garantir a subsistência do grupo. As consequências eram basicamente duas: $i$ ) ou os demais familiares deveriam ampliar a carga horária de trabalho para garantir o nível de renda mínimo para a sobrevivência ou $i$ ) o grupo passaria por um período penoso do ponto de vista alimentar. 
A plantation açucareira, em Pernambuco, instituiu, por meio de uma perfeita aritmética da exaustáo, uma duradoura indústria dos corpos exauridos. Secularmente pensadas, embora nem sempre claramente manifestadas, as distinçóes sociais instituídas nesse espaço podiam ser vistas sob vários aspectos que, embora separados, coadunavam-se formando um amálgama perfeito: i) da violência física (como fator econômico, na medida em que, por vias diversas, ampliava a margem de lucros das empresas; e fator social, inscrito na longa duraçáo) contra trabalhadores; ii) da fome, que elegia os pobres como seu templo maior; e iii) dos acidentes e das doenças do trabalho que perseguiam os corpos cansados dos canavieiros.

As mazelas da cana, de fato, faziam parte de um arquétipo de produção firmado para explorar os despossuídos. Embora as relaçôes de trabalho não fossem condicionantes necessários do processo de adoecimento dos trabalhadores, as condições impostas pelos detentores dos meios de produção e a falta de escolhas daqueles que tinham a própria força de trabalho como único bem a vender representavam a base sobre a qual se firmavam as ligaçôes entre desigualdade de poder, trabalho e doenças na plantation açucareira. Nesse sentido, este artigo buscou, basicamente, identificar como esse processo de adoecimento estava intimamente ligado ao trabalho nos engenhos e nas usinas. A histórica exploração do corpo do trabalhador, instituída na plantation ao longo de séculos, permaneceu como marca indelével de sua estrutura. Sem amparo legal por parte do Estado, como nos casos ilustres de nossos interlocutores (José e Maria Gomes), no início deste artigo, os moradores de engenho que viviam isolados nesses territórios desconhecidos eram submetidos a toda sorte de infortúnios. Eles foram vítimas, e não, vetores dos próprios males.

\section{REFERÊNCIAS}

ALENCAR, Eloine Nascimento de. Trabalho e saúde do canavieiro. João Pessoa: Mestrado em Enfermagem em Saúde Pública/UFPB, 1993. 
AZEVEDO, Carlos Alberto; CALDAS, Rachel; CHACON, Vamireh. Situaçáo socioeconômica em áreas da zona canavieira de Pernambuco e Alagoas. Recife: IJNPS, 1972.

BARBOSA, C. S. et al. Esquistossomose: reprodução e expansão da endemia no estado de Pernambuco no Brasil. Revista de Saúde Pública, v.30 n.6, 1996.

BATISTA FILHO, Malaquias et al. Pesquisa Nutricional na Zona da Mata. Recife: UFPE Imprensa universitária, 1968.

BATISTA FILHO, Malaquias; SHIRAIWA, Tizuko. Indicadores de saúde para um sistema de vigilância nutricional. Cadernos de Saúde Pública, v.5, n.1, p.105-116, 1989.

BERNARDES, Denis A. de M. Octávio Ianni e a Questáo Nordeste. In: COSTA LIMA, Marcos (org.). A Sociologia de Octávio Ianni: uma abordagem. Recife: EDUFPE, 2005.

BOHAN, Merwin L. (coord.). Northeast Brazil: Nutrition Study, March-May 1963. Washington: Department of Defense, 1965.

CABRAL, Pedro Eugênio T. Tempo de morada: a constituição do mercado de trabalho semi-assalariado na lavoura canavieira Pernambucana. In: SAMPAIO, Yoni. Nordeste rural: a transição para o capitalismo. Recife: Ed. Universitária, 1987.

CANÇADO, José Eduardo Delfini. A poluiçáo atmosférica e sua relaçáo com a saúde humana na regiáo canavieira de Piracicaba - SP. São Paulo: Tese de Doutorado em Medicina/ USP, 2003.

CASTRO, Josué de. Geografia da fome. São Paulo: Brasiliense, 1961. 
CHAUCHARD, Paul. La fatigue : que sais-je ? Le point des connaissances actuelles. Paris: Presses Universitaires de France, 1959.

CHAVES, Nelson. Ecologia e Nutrição: observação no trópico úmido. In: CHAVES, Nelson. O homem além do tempo: a palavra de um cientista que amava sua terra e sua gente. Coletânea de Artigos. Universidade Federal de Pernambuco, EDUFPE, 2007.

CONDEPE/FIDEM - Agência Estadual de Planejamento e Pesquisa de Pernambuco. Levantamento sócio-econômico das pequenas localidades na Zona da Mata Sul - v. I e II. Recife: Secretaria de Planejamento, Fundaçáo de Desenvolvimento $\mathrm{Mu}-$ nicipal do Interior de Pernambuco (FIAM), 1987.

DABAT, Christine Rufino. Moradores de engenho: estudo sobre as relaçóes de trabalho e condiçóes de vida dos trabalhadores rurais na zona canavieira de Pernambuco, segundo a literatura, a academia e os próprios atores sociais. Recife: 2.ed., EdUFPE, 2012.

FERREIRA FILHO, José Marcelo Marques. Malandragem e corpo mole: a naturalização das doenças do trabalho no discurso da classe patronal canavieira em Pernambuco (1960-1975). Gênero \& História, v.VII, 2011.

FERREIRA FILHO, José Marcelo Marques. Corpos exauridos: relaçóes de poder, trabalho e doenças nas plantaçóes açucareiras (Zona da Mata de Pernambuco, 1963-1973). Recife: Dissertação de Mestrado em História/UFPE, 2012.

GARCIA, Marie France. O Bacurau: étude de cas d'un marche situe dans une usina. Rio de Janeiro: Dissertação de Mestrado em Antropologia Social/Museu Nacional, 1977. 
HEREDIA, Beatriz Maria Alásia. Formas de dominaçáo e espaço social: a modernização da agroindústria canavieira em Alagoas. São Paulo: Marco Zero, 1988.

LINHART, Robert. O açúcar e a fome: pesquisas nas regiôes açucareiras do Nordeste do Brasil. Rio de Janeiro: Paz e Terra, 1981.

LOPES, José Sérgio Leite. O vapor do diabo: o trabalho dos operários do açúcar. Rio de Janeiro: Paz e Terra, 1978.

MOZA, Patrícia Ganzenmüller; PIERI, Otávio Sarmento; BARBOSA, Constança Simóes; REY, Luís. Fatores sócio-demográficos e comportamentais relacionados à esquistossomose em uma agrovila da zona canavieira de Pernambuco, Brasil. Cadernos de Saúde Pública, v.14, n.1, p.107-115, jan/mar 1998.

PAGE, Joseph. A Revoluçáo que nunca houve: o Nordeste do Brasil 1955-1964. Traduçẫo: Ariano Suassuna. Rio de Janeiro: Record, 1972.

PAIXÃO, Marcelo Jorge de Paula. No coraçáo do canavial: estudo crítico da evoluçáo do complexo agroindustrial sucro-alcooleiro e das relaçóes de trabalho na lavoura canavieira. Rio de Janeiro: Dissertação de Mestrado em Engenharia de Produção/ UFRJ, 1994.

PIMENTEL, David; PIMENTEL, M. Food, Energy and Society. London, 1979.

PORTELLA, T.; AAMOT, D.; PASSAVANTE, Z. Homemgabiru: catalogação de uma espécie. São Paulo: Hucitec, 1992.

SPURR, G. B.; BARAC-NIETO, M.; MAKSUD, M. G. Productivity and maximal oxygen consumption in sugar cane cutters. American Journal of Clinical Nutrition, v.30, p.316-321, 
1977.

SPURR, G. B.; BARAC-NIETO, M.; MAKSUD, M. G. Efficiency and daily work effort in sugar cane cutters. British Journal of Industrial Medicine, v.34, n.2, p.137-41, May 1977.

SPURR, G. B.; BARAC-NIETO, M.; MAKSUD, M. G. Energy expenditure cutting sugarcane. Journal of Applied Psychology, v.39, n.6, p.990-996, 1975.

SPURR, G. B.; BARAC-NIETO, M.; MAKSUD, M. G. Energy expenditure, productivity, and physical work capacity of sugarcane loaders. The American Journal of Clinical Nutrition, v. 30, p.1740-1746, Oct.1977.

SATYANARAYANA, K.; NAIDU, A.N.; CHATTERJEE, B.; RAO, N. Body size and work output. American Journal of Clinical Nutrition, v. 30, p. 322-325, 1977.

THOMAZ JÚNIOR, Antônio. Não há nada de Novo sob o Sol num Mundo de Heróis! (A Civilização da Barbárie na Agroindústria Canavieira). Pegada, Presidente Prudente, v.8, n.2, dez. 2007.

VALENÇA, Vanessa. Condiçóes de trabalho, produtividade e riscos à saúde do trabalhador na atividade do corte manual de cana: um estudo de caso na Usina Santa Adélia. São Carlos: Dissertação de Mestrado em Engenharia de Produção/ UFSCar, 2007.

VITERI, Fernando; TORUN, Benjamín. Ingestión calórica y trabajo físico de obreros agrícolas en Guatemala: efecto de la suplementación alimentaria y su lugar en los programas de salud. Boletín de la Oficina Sanitaria Panamericana, v.78, p.58-74, 1975. 


\section{JORNAIS E REVISTAS CONSULTADOS}

A Folha de Sáo Paulo, 19 de novembro de 1991.

Veja, 18 de dezembro de 1991.

Diário de Pernambuco, 15 de janeiro de 1997.

\section{ARQUIVOS CONSULTADOS}

Arquivo do Hospital Barão de Lucena

Arquivo do Tribunal Regional do Trabalho (6a Regiáo) 